\title{
Pulmonary carcinoid tumours: a comparative regional study
}

\author{
T. COONEY, E. C. SWEENEY, AND D. LUKE
}

From the Department of Histopathology and Morbid Anatomy, Trinity College and the Thoracic Surgery Unit, Royal City of Dublin Hospital, Dublin, Eire

SUMmaRY Twenty-two pulmonary carcinoid tumours (18 central, 4 peripheral) were seen in this department over an 11-year period. The majority of the tumours displayed a mixed pattern on microscopic examination, and cell-nest formation was a prominent feature in sixteen. The findings are at variance with the results of a similar series reported from Japan and suggest that there is regional variation in the tumour pattern of pulmonary carcinoids. Various aspects of the histopathology are discussed, and a causal relationship between ossification of bronchial cartilage in these tumours and locally produced calcitonin is postulated.

There have been numerous reports of series of pulmonary carcinoid tumours over the past 17 years. A review of the literature reveals the characteristic mode of presentation, features of prognostic significance, and the range of histological appearances of tumours. Most reports, however, have emanated from centres in the western hemisphere (Table 1), particularly the United States, and it is possible that

Table 1 Series of bronchial carcinoid tumours according to geographic location

\begin{tabular}{lll}
\hline Location & Author & Year \\
\hline USA & Goodner et al. & 1961 \\
USA & Weiss and Ingram & 1961 \\
USA & Markel et al. & 1964 \\
USA & Donahue et al. & 1968 \\
England & Smith & 1969 \\
USA & Meffert and Lindskog & 1970 \\
USA & O'Grady et al. & 1970 \\
Japan & Soga and Tazawa & 1971 \\
USA & Arrigoni et al. & 1972 \\
USA & Tolis et al. & 1972 \\
USA & Turnbull et al. & 1972 \\
Denmark & Burcharth and Axelsson & 1973 \\
Denmark & Hage & 1973 \\
France & Renault and Verley & 1973 \\
Finland & Koikkalainen et al. & 1974 \\
USA & Godwin & 1975 \\
USA & Salyer et al. & 1975 \\
USA & Bonikos et al. & 1976 \\
England & Lawson et al. & 1976 \\
USA & Okike et al. & 1976 \\
USA & Marks and Lamberty & 1977 \\
England & Jones and Dawson & 1977 \\
USA & Fisher et al. & 1978 \\
\hline
\end{tabular}

Received for publication 30 January 1979 the data derived from these studies might not be representative of pulmonary carcinoid tumours in other populations. Accepting the premise that there are racial differences in the occurrence and distribution of argyrophil cells in adult human lungs (Tateishi, 1973), it is possible that tumours derived from these cells (Bensch et al., 1965, 1968; Gmelich et al., 1967) might also display racial variation in their incidence, distribution, or composition. Some support for this suggestion has been provided by Godwin (1975), who showed a significant difference in the incidence of pulmonary carcinoid tumours in white and black populations of the United States. We have reviewed a series of 22 pulmonary carcinoids occurring in adults in Ireland and have compared our findings, particularly in relation to tumour composition, with those of similar studies performed elsewhere.

\section{Material and methods}

Formalin-fixed tissue obtained at thoracotomy was examined in each case. The tissue was routinely processed and embedded in paraffin. Sections were stained with haematoxylin and eosin, Alcian blue, and Congo red and by the Weigert-van Gieson method for connective tissue and elastic. The Masson-Fontana technique was utilised for demonstration of argentaffin cells and the Grimelius and modified Bodian techniques for demonstration of argyrophilia. Solcia's lead haematoxylin method was also used for the demonstration of endocrine cell granules. In 10 cases sections were incubated with 
rabbit antiserum to human calcitonin ${ }^{1}$ and stained by a peroxidase technique (Burns, 1975). Sections of a medullary carcinoma of the thyroid were used as a positive control. Small portions of tumour from the more recent cases were washed in cacodylate buffer, transferred to $0.3 \%$ glutaraldehyde, and postfixed in $0.1 \%$ osmium tetroxide. Blocks were embedded in epon and sections were stained with uranyl acetate/lead citrate. The sections were examined using a Jeol 100 CX TEM. Tumours arising from subsegmental bronchi and distal bronchioles were designated 'peripheral' carcinoids.

\section{Observations and results}

The clinical presentation and radiological findings, ${ }^{1}$ Antihuman calcitonin antiserum kindly supplied by $\mathrm{Dr}$ F. T. Bosman, Leiden, Holland. together with tumour site and size, presence or absence of metatases, and results of treatment are given in Table 2. These data do not show significant divergence from those documented in other series. None of the patients had evidence of carcinoid syndrome.

\section{MICROSCOPIC FEATURES}

The majority of tumours were composed of uniform cells with round to oval nuclei containing coarse chromatin strands and one or two small nucleoli. The cells possessed moderate amounts of granular eosinophilic cytoplasm and distinct cell borders. Significant mitotic activity was present in five tumours, four of which (cases 7, 16, 19, and 22) showed the additional features of focal necrosis and nuclear pleomorphism associated with the atypical variant of pulmonary carcinoid (Arrigoni

Table 2 Clinical data on 22 patients with pulmonary carcinoid tumour

\begin{tabular}{|c|c|c|c|c|c|c|c|c|c|c|}
\hline \multirow[t]{2}{*}{ Case } & \multirow{2}{*}{$\begin{array}{l}\text { Agel } \\
\text { Sex }\end{array}$} & \multirow{2}{*}{$\begin{array}{l}\text { Clinical } \\
\text { presentation }\end{array}$} & \multirow{2}{*}{$\begin{array}{l}\text { Radiological } \\
\text { features }\end{array}$} & \multirow{2}{*}{$\begin{array}{l}\text { Tumour } \\
\text { location }\end{array}$} & \multirow{2}{*}{$\begin{array}{l}\text { Size } \\
(\mathrm{cm})\end{array}$} & \multirow[t]{2}{*}{ Operation } & \multicolumn{2}{|c|}{ Metastases } & \multirow{2}{*}{$\begin{array}{l}\text { Date of } \\
\text { operation }\end{array}$} & \multirow[t]{2}{*}{ Results } \\
\hline & & & & & & & Nodal & Distant & & \\
\hline 1 & $19 \mathrm{M}$ & $\begin{array}{l}\text { Haemoptysis } \\
\text { and recurrent } \\
\text { pneumonia }\end{array}$ & $\begin{array}{l}\text { LLL con- } \\
\text { solidation }\end{array}$ & LLL central & $1 \cdot 5$ & LL lobectomy & - & - & 1967 & Well at 5 yr \\
\hline 2 & $47 \mathrm{M}$ & $\begin{array}{l}\mathbf{R} \text { scapular } \\
\text { pain }\end{array}$ & $\mathbf{R}$ hilar opacity & RLL peripheral & $2 \cdot 0$ & $\begin{array}{l}\text { Peripheral RLL } \\
\text { resection }\end{array}$ & NE & - & 1969 & Lost to follow-up \\
\hline 3 & $29 \mathrm{~F}$ & Cough & $\mathbf{R}$ basal opacity & RML central & $1 \cdot 5$ & $\begin{array}{l}\mathbf{R M} \text { and } \mathbf{R L} \\
\text { lobectomy }\end{array}$ & - & - & 1969 & Well at 9 yr \\
\hline 4 & $60 \mathrm{M}$ & Haemoptysis & RUL opacity & RUL central & 0.5 & RU lobectomy & - & - & 1970 & Well at $4 \mathrm{yr}$ \\
\hline 5 & $56 \mathrm{~F}$ & Haemoptysis & $\begin{array}{l}\mathrm{R} \text { midzone } \\
\text { opacity }\end{array}$ & RUL central & $1 \cdot 5$ & RU lobectomy & NE & - & 1971 & Well at 6 yr \\
\hline 6 & $52 \mathrm{~F}$ & Pneumonia & $\mathbf{R}$ hilar opacity & RUL central & $2 \cdot 0$ & RM lobectomy & NE & - & 1972 & Well at $5 \mathrm{yr}$ \\
\hline 7 & $55 \mathrm{~F}$ & $\begin{array}{l}\text { Cough. R chest } \\
\text { 'soreness' }\end{array}$ & $\begin{array}{l}\mathbf{R} \text { apical } \\
\text { opacity }\end{array}$ & RUL central & $?$ & RU lobectomy & $\mathbf{N E}$ & - & 1974 & Well at $3 \mathrm{yr}$ \\
\hline 8 & $59 \mathrm{M}$ & Cough & RUL opacity & RUL peripheral & $2 \cdot 0$ & RU lobectomy & - & - & 1977 & Well at $4 \mathrm{mth}$ \\
\hline 9 & $51 \mathrm{M}$ & $\begin{array}{l}\text { Haemoptysis } \\
\text { and } \\
\text { pneumonia }\end{array}$ & RLL collapse & RLL central & 6.0 & $\begin{array}{r}\mathbf{R M} \text { and } \mathbf{R L} \\
\text { lobectomy }\end{array}$ & - & - & 1977 & Well at $6 \mathrm{mth}$ \\
\hline 10 & $55 \mathrm{~F}$ & $\begin{array}{l}\text { L chest pain. } \\
\text { Haemoptysis }\end{array}$ & L lung collapse & $\begin{array}{l}\text { L main bron- } \\
\text { chus, central }\end{array}$ & $5 \cdot 0$ & $\begin{array}{c}\text { L pneumo- } \\
\text { nectomy }\end{array}$ & - & - & 1975 & Well at $3 \mathrm{yr}$ \\
\hline 11 & $59 \mathrm{M}$ & Asymptomatic & $\begin{array}{l}\text { Coin lesion } \mathbf{L} \\
\text { midzone }\end{array}$ & LUL peripheral & $\underset{1 \cdot 0}{<}$ & $\begin{array}{l}\text { Peripheral LUL } \\
\text { resection }\end{array}$ & - & - & 1976 & Well at $1 \mathrm{yr}$ \\
\hline 12 & $57 \mathrm{~F}$ & Cough & L lung collapse & $\begin{array}{l}\mathbf{L} \text { main bron- } \\
\text { chus, central }\end{array}$ & $2 \cdot 5$ & $\begin{array}{l}\text { L pneumo- } \\
\text { nectomy }\end{array}$ & - & - & 1974 & Well at $4 \mathrm{yr}$ \\
\hline 13 & $58 \mathrm{~F}$ & $\begin{array}{l}\text { Cough. } L \text { chest } \\
\text { pain }\end{array}$ & $\begin{array}{l}\text { LUL con- } \\
\text { solidation }\end{array}$ & $\begin{array}{l}\text { L lingular bron- } \\
\text { chus, central }\end{array}$ & $3 \cdot 0$ & LU lobectomy & - & - & 1975 & Well at 2 yr \\
\hline 14 & $53 \mathrm{~F}$ & Cough & $\begin{array}{l}\text { LLL con- } \\
\text { solidation }\end{array}$ & LLL central & $5 \cdot 0$ & LL lobectomy & - & + Liver & 1975 & Metastases at $2 \mathrm{yr}$ \\
\hline 15 & $38 \mathrm{M}$ & $\begin{array}{l}\text { Recurrent } \\
\text { pneumonia }\end{array}$ & $\begin{array}{l}\text { LU hilar } \\
\text { opacity }\end{array}$ & LUL central & $1 \cdot 5$ & LU lobectomy & - & - & 1974 & Well at $3 \mathrm{yr}$ \\
\hline 16 & $40 \mathrm{M}$ & $L$ chest pain & LUL opacity & LUL central & $5 \cdot 0$ & LU lobectomy & + & $+\underset{\text { spleen }}{\text { Lung }}$ & 1977 & $\begin{array}{l}\text { Postoperative } \\
\text { death }\end{array}$ \\
\hline 17 & $39 \mathrm{~F}$ & $\begin{array}{l}\text { R chest pain. } \\
\text { Recurrent } \\
\text { pneumonia }\end{array}$ & RLL opacity & RLL central & $5 \cdot 0$ & $\begin{array}{r}\text { RM and RL } \\
\text { lobectomy }\end{array}$ & - & - & 1978 & Well at $6 \mathrm{mth}$ \\
\hline 18 & $36 \mathrm{M}$ & No details & RML opacity & RML central & $1 \cdot 5$ & RM lobectomy & NE & - & 1972 & Lost to follow-up \\
\hline 19 & $32 \mathrm{~F}$ & No details & L hilar opacity & LUL central & $4 \cdot 0$ & $\begin{array}{l}\text { L pneumo- } \\
\text { nectomy }\end{array}$ & NE & + Brain & 1973 & Died at 2 yr \\
\hline 20 & $57 \mathrm{~F}$ & $\begin{array}{l}\text { L chest pain. } \\
\text { Haemoptysis }\end{array}$ & L hilar opacity & LLL central & $2 \cdot 0$ & LL lobectomy & - & - & 1971 & Lost to follow-up \\
\hline 21 & $70 \mathrm{M}$ & $\mathbf{R}$ chest pain & $\begin{array}{l}\text { Coin lesion } \mathbf{R} \\
\text { lung }\end{array}$ & $\begin{array}{l}\mathbf{R} \text { lung } \\
\text { peripheral }\end{array}$ & $<$ & $\begin{array}{l}\text { Peripheral RLL } \\
\text { resection }\end{array}$ & $\mathbf{N E}$ & - & 1971 & Well at 2 yr \\
\hline 22 & $65 \mathrm{~F}$ & Haemoptysis & RLL collapse & RLL central & $9 \cdot 0$ & $\begin{array}{r}\text { RM and RL } \\
\text { lobectomy }\end{array}$ & + & - & 1978 & Well at $2 \mathrm{mth}$ \\
\hline
\end{tabular}

$\mathrm{NE}=$ not examined, + present, - not present 
et al., 1972). Anisonucleosis without pleomorphism was present in five tumours, two of which were peripheral. One centrally located tumour was composed predominantly of spindle-shaped cells (Fig. 1). No oncocytic variants were seen in this series.
A striking feature in seven cases was the presence of bone formation in bronchial cartilage which was contiguous with or had been engulfed by tumour. In most cases the bone formation appeared to have taken place in close relation to the perichondrium

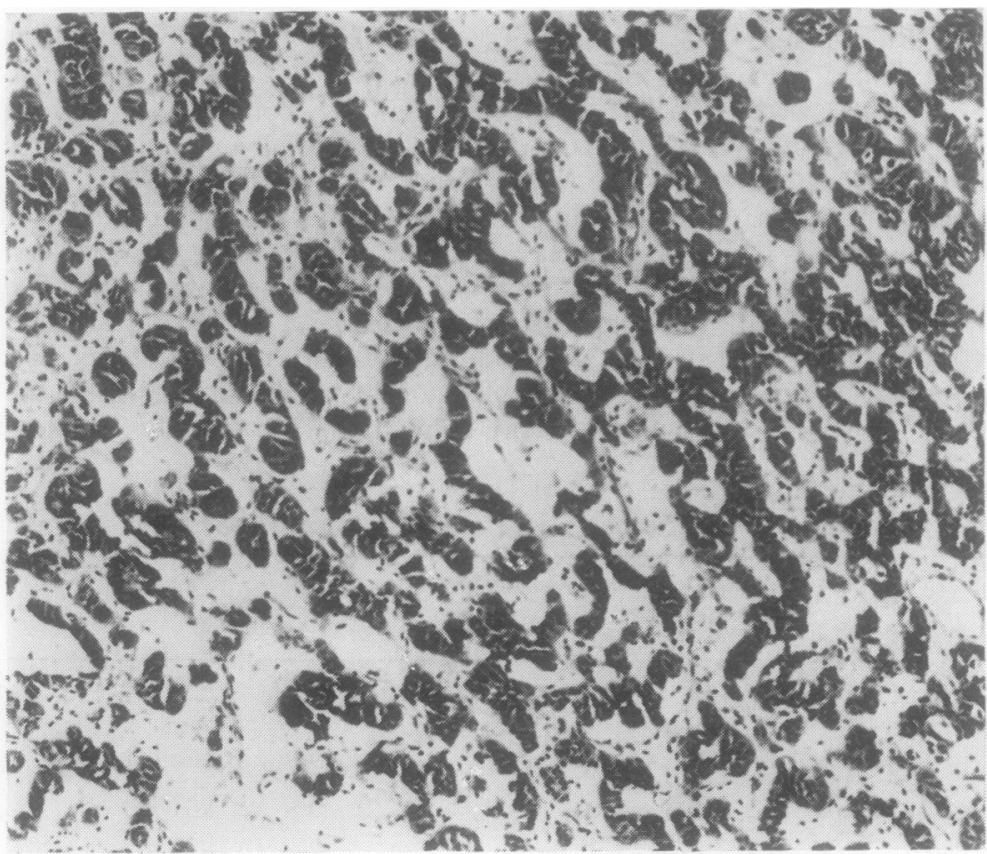

Fig. 1a

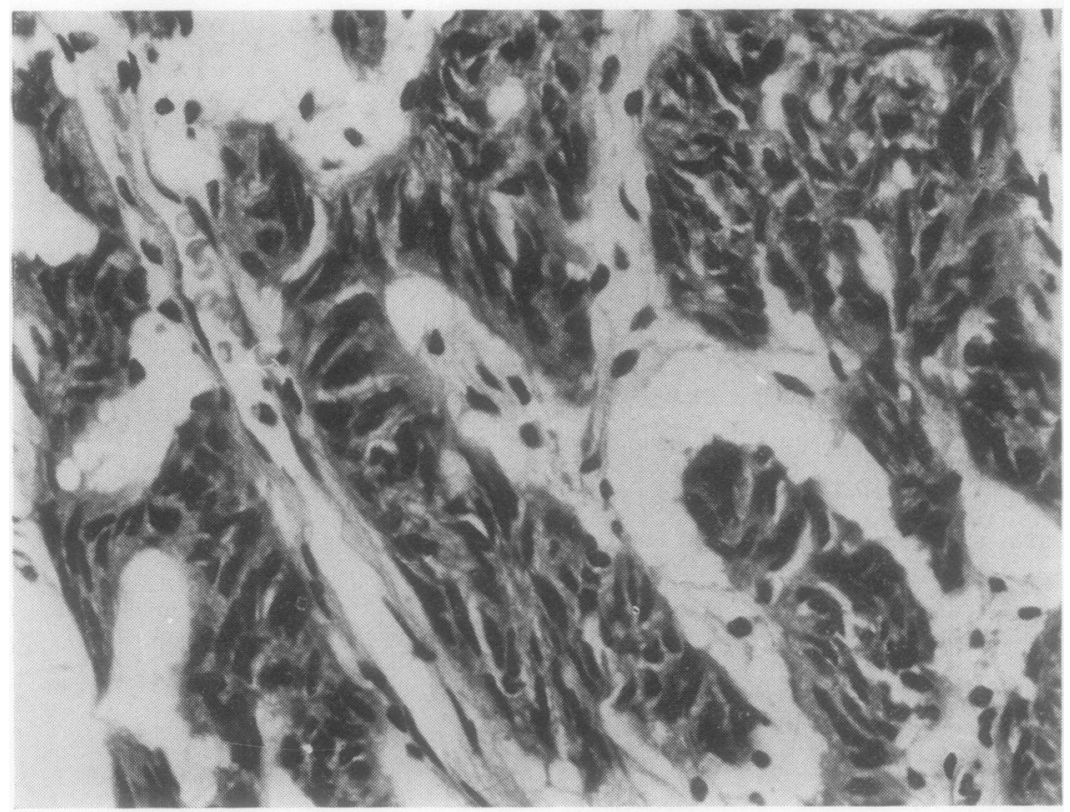

Fig. 1 Spindle-cell tumour showing (a) trabecular pattern and (b) cell morphology. (a) $\mathrm{H}$ and $E \times 50 ;(b) H$ and $E \times 500$. 


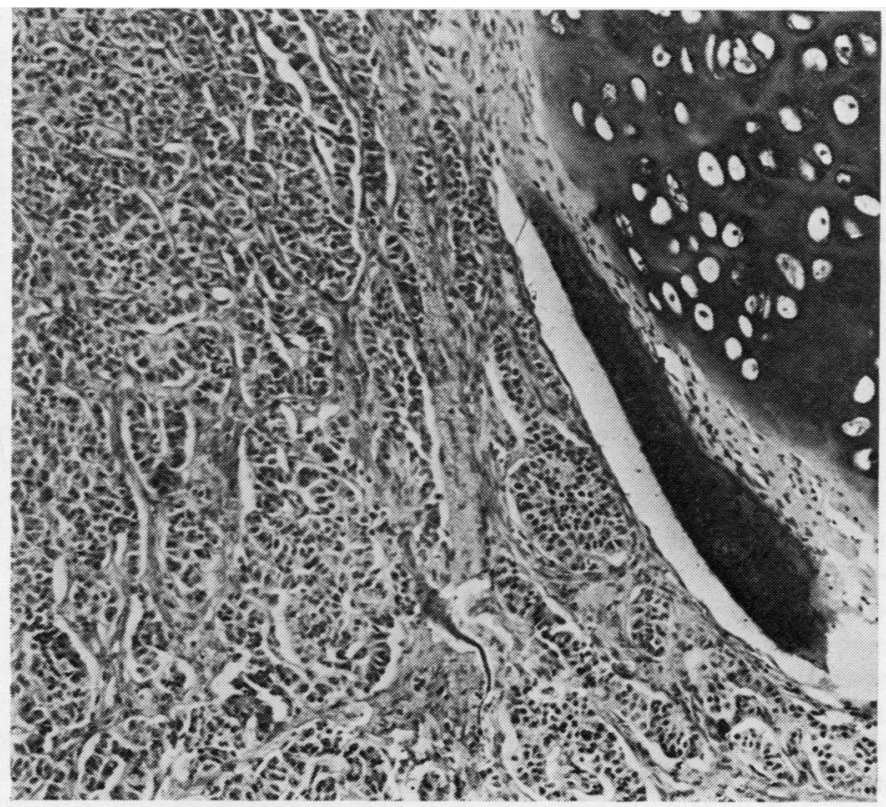

Fig. 2a

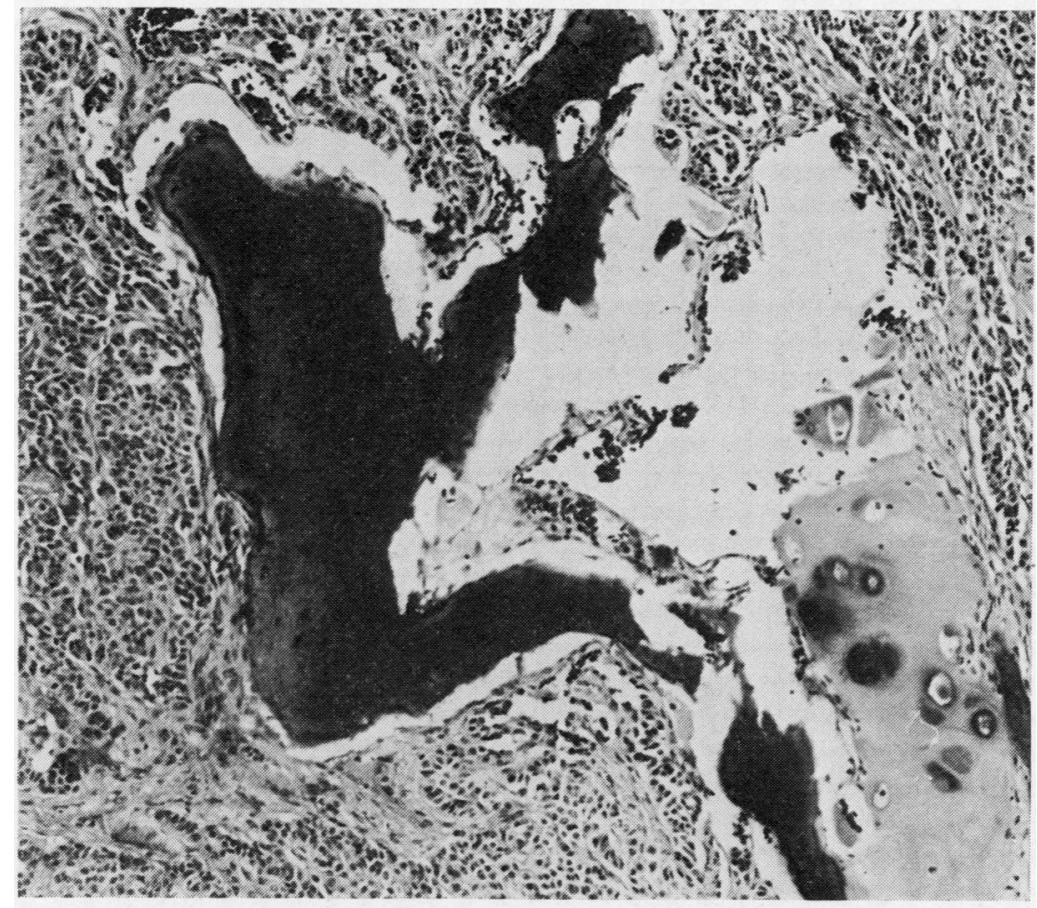

Fig. 2 Bone formation in relation to bronchial cartilage The earliest change visualised. (a) Consists of bone developing in close relation to the tumour but separated from cartilage by perichondrium. (b) Demonstrates more extensive bone formation around cartilage engulfed by tumour. (a) $H$ and $E \times 50$; (b) $H$ and $E \times 50$.

Fig. 2b 
(Fig. 2) and in some instances marrow development within the bone was evident. The histological pattern of the tumours was very varied. Cell nest formation (Fig. 3) was evident in 16 cases and trabeculation (Fig. 4) in 16 (not always coincident). A tubular, acinar, or rosette pattern was noted in eight tumours (Fig. 5). The spindle-cell tumour displayed a predominantly trabecular pattern with elongated and condensed nuclei of variable size. The tumour stroma in most cases consisted of a delicate fibrovascular network, although case 7 showed a markedly expanded and hyalinised fibrous stroma with heavy perivascular elastosis. Four patients $(18 \%)$ had metastatic disease. These included three of the patients with atypical carcinoid and case 14 . The latter tumour appeared innocuous at surgery and despite minimal mitotic activity was classified as a typical carcinoid. In common with occasional cases of typical pulmonary carcinoid documented by other authors (Arrigoni et al., 1972), the patient developed distant metastases two years postoperatively. Perineural invasion was evident in two cases (7 and 9), neither of which metastasised, although one (case 7) had a high mitotic rate.

The tumours in this series were classified according to the system devised by Soga and Tazawa (1971) to facilitate comparison, and the results are given in Table 3 . In this system, types A, B, and C denote tumours composed basically of cell nests, trabeculae, or tubules respectively. Type D includes tumours 'with structures of lower or atypical differentiations', and mixed type is the term used for tumours with any combination of the preceding types. In 15 of our cases $(68 \%)$, a mixed pattern was evident, the remaining seven cases $(32 \%)$ being of an unmixed or 'pure' type. Of the four atypical tumours $(18 \%)$, one consisted of cell nests only whereas the remainder showed a mixed pattern and were classified as such. Three of the four peripheral tumours were of a 'pure' type, a very high proportion relative to the overall series composition.

\section{STAINING PROPERTIES}

The results of special staining procedures are listed in Table 4. Argentaffin reaction and staining for amyloid were uniformly negative. Twelve tumours (54\%) were argyrophilic and five $(23 \%)$ contained alcianophilic material, both within the cytoplasm of cells and within distinct tubular lumina. The lead haematoxylin stain proved fickle, definite positivity being found in only five of the 12 argyrophil tumours. It is of interest that while ossification did not appear to be significantly related to any particular histological pattern in this series it was more common in argyrophilic tumours. Of the 10 tumours stained by an immunoperoxidase technique for calcitonin, there was a positive correlation between the presence or absence of bone and the presence or absence of calcitonin containing cells in eight (Fig. 6). In the remaining two cases, calcitonin was present but bone

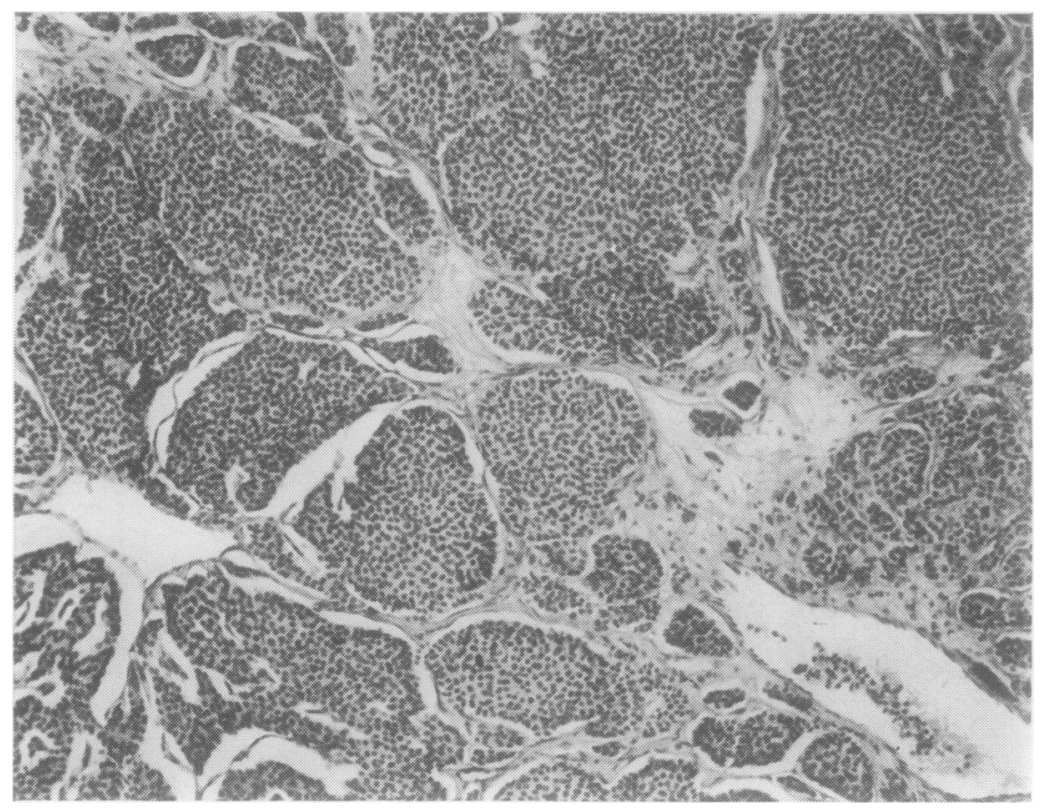

Fig. 3 Cell-nest formation. Groups of uniform cells separated by delicate fibrovascular stroma. $\boldsymbol{H}$ and $E \times 50$. 


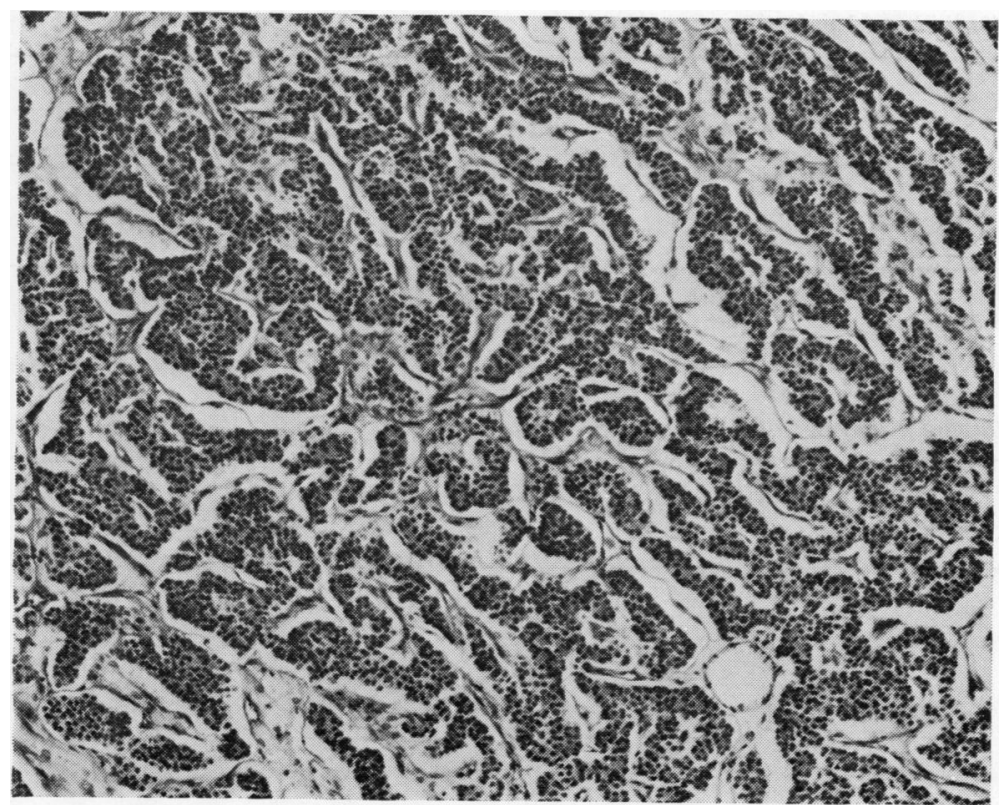

Fig. 4 Trabecular pattern. Uniform cells arranged in anastomosing cords separated by loose connective tissue. $\mathrm{H}$ and $E \times 50$.

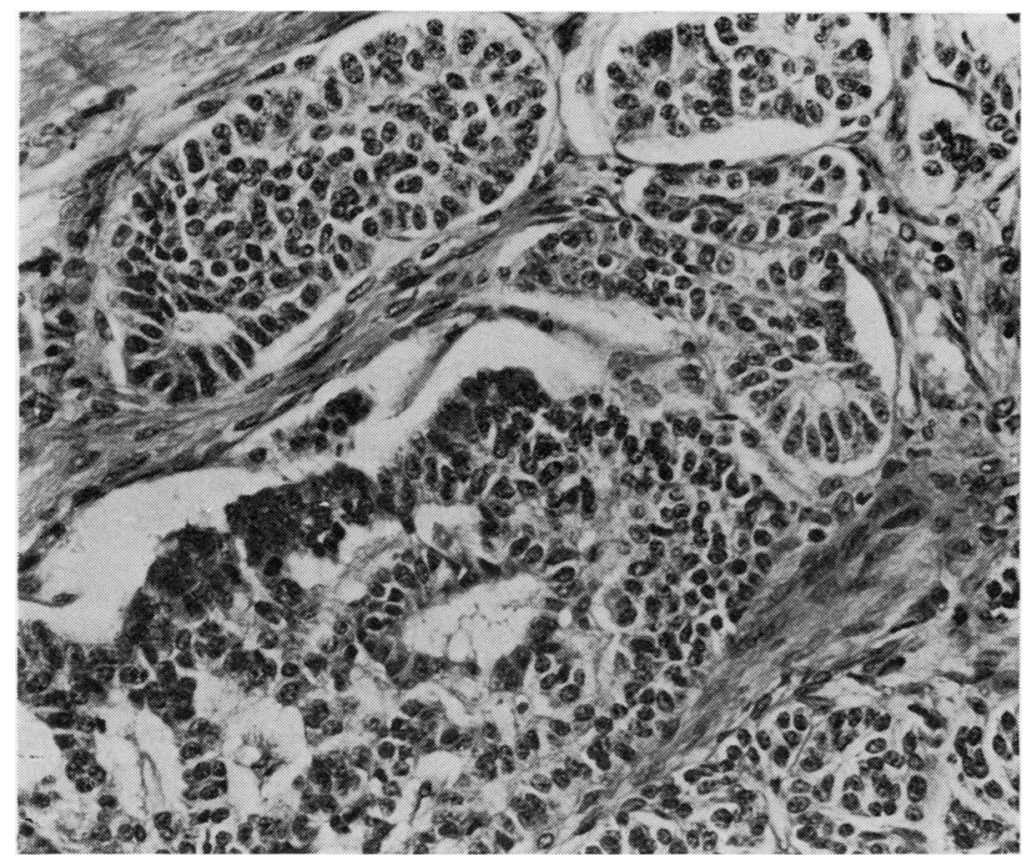

Fig. 5. Tubular arrangement of cells evident in areas of eight tumours. $H$ and $E \times 310$.

was not identified in the sections examined. The number of calcitonin containing cells in each tumour was very small and bore no relationship to the degree of argyrophilia.
ELECTRON MICROSCOPY

In the cases studied by this method $(8,16,17$, and 22) characteristic neurosecretory granules were easily identified in the cells. Lumina lined by 
Table 3 Histological types and distribution of 22 pulmonary carcinoids

\begin{tabular}{|c|c|c|c|c|c|c|c|c|}
\hline \multirow{2}{*}{$\begin{array}{l}\text { Location } \\
\text { in lung }\end{array}$} & \multirow{2}{*}{$\begin{array}{l}\text { Nests } \\
\text { A }\end{array}$} & \multirow{2}{*}{$\begin{array}{l}\text { Trabeculae } \\
\text { B }\end{array}$} & \multirow{2}{*}{$\begin{array}{l}\text { Tubules or } \\
\text { rosettes } \\
C\end{array}$} & \multicolumn{4}{|l|}{ Mixed } & \multirow[t]{2}{*}{ Total } \\
\hline & & & & $A+B$ & $B+C$ & $A+C$ & $A+B+C$ & \\
\hline $\begin{array}{l}\text { Central } \\
\text { Peripheral } \\
\text { Total }\end{array}$ & $\begin{array}{l}2^{*} \\
2 \\
4\end{array}$ & $\begin{array}{l}2 \\
1 \\
3\end{array}$ & $\begin{array}{l}0 \\
0 \\
0\end{array}$ & $\begin{array}{l}7^{*} \\
0 \\
7\end{array}$ & $\begin{array}{l}3 \\
0 \\
3\end{array}$ & $\begin{array}{l}2 \dagger \\
0 \\
2\end{array}$ & $\begin{array}{l}2 \\
1 \\
3\end{array}$ & $\begin{array}{r}18 \\
4 \\
22\end{array}$ \\
\hline
\end{tabular}

* One tumour of each of these groups

+Both tumours of this group showed atypical features

(D type: Soga and Tazawa (1971))

Table 4 Histological features and staining properties of 22 pulmonary carcinoids

\begin{tabular}{|c|c|c|c|c|c|c|c|c|c|c|}
\hline No. & $\begin{array}{l}\text { Pattern } \\
\text { (Soga and } \\
\text { Tazawa, 1971) }\end{array}$ & $\begin{array}{l}\text { Mitoses per } \\
10 \mathrm{HPF}\end{array}$ & Necrosis & Bone & $\begin{array}{l}\text { Perineural } \\
\text { invasion }\end{array}$ & $\begin{array}{l}\text { Nuclear } \\
\text { variability }\end{array}$ & Mucin & Argyrophilia & $\begin{array}{l}\text { Lead } \\
\text { haematoxylin }\end{array}$ & Calcitonin \\
\hline 2 & A & - & - & - & - & + & - & - & - & ND \\
\hline 3 & $\mathbf{A}$ & - & - & - & - & - & - & + & + & ND \\
\hline 4 & $\mathbf{A}+\mathbf{B}$ & - & - & + & - & - & - & - & - & ND \\
\hline 5 & B & - & - & - & - & + & - & - & - & ND \\
\hline 7 & $\mathbf{B}+\mathbf{C}$ & 5 & + & - & + & - & - & - & - & - \\
\hline 8 & $\mathbf{A}+\mathbf{B}+\mathbf{C}$ & - & - & - & - & - & - & - & - & ND \\
\hline 9 & $\mathbf{A}+\mathbf{B}+\mathbf{C}$ & - & - & + & + & + & - & + & - & + \\
\hline 10 & B & - & - & - & - & - & - & + & + & - \\
\hline 11 & B & - & - & - & - & - & + & - & - & - \\
\hline 12 & $\mathbf{A}+\mathbf{B}$ & - & - & - & - & - & - & + & - & + \\
\hline 13 & $\mathbf{B}+\mathbf{C}$ & - & - & - & - & - & - & + & - & ND \\
\hline 14 & $\mathbf{A}+\mathbf{B}$ & 2 & - & + & - & - & - & + & - & + \\
\hline 17 & $\mathbf{A}+\mathbf{B}$ & - & - & - & - & - & - & + & - & + \\
\hline 18 & $\mathbf{A}+\mathbf{B}$ & - & - & - & - & - & - & - & - & ND \\
\hline 19 & A & 10 & $+t$ & + & - & - & - & + & + & ND \\
\hline 20 & $\mathbf{A}+\mathbf{B}$ & - & - & + & - & - & - & + & - & + \\
\hline 21 & A & - & - & - & - & - & - & - & - & - \\
\hline 22 & $\mathbf{A}+\mathbf{C}$ & 40 & +++ & - & - & + & $+t+$ & + & - & ND \\
\hline
\end{tabular}

ND $=$ not done

microvilli were identified in case 16 , the ultrastructure of which has been documented elsewhere (Sweeney and Cooney, 1978). The other mucin-producing atypical tumour in this series (case 22) contained intracytoplasmic mucin (Fig. 7) but, in keeping with its lesser degree of structural differentiation when compared with case 16 , lumina or canaliculi were not readily identified electron microscopically.

\section{Discussion}

The predominant pattern in our series was that of a mixed tumour type similar to that documented in England by Jones and Dawson (1977) and in the United States by Salyer et al. (1975). In contrast, $50 \%$ of the bronchial carcinoids and the majority of foregut carcinoids described by Soga and Tazawa (1971) in Japan were of the pure trabecular type. The significance of this regional variation is difficult to assess because other workers in both England and the United States (Williams and Sandler, 1963;
Markel et al., 1964; Fisher et al., 1978) also recognise the trabecular arrangement as the commonest growth pattern in bronchial and other foregut carcinoids although precise comparison between their series and that of Soga and Tazawa (1971) is not possible.

In $16(72 \%)$ of our cases the tumour demonstrated cell-nest formation, a feature of two-thirds of the cases recorded by Jones and Dawson (1977) and most of the cases of Salyer et al. (1975). In the Japanese series, however, cell-nest formation was present in only a minority of foregut carcinoids (Soga and Tazawa, 1971). The apparent differences between the structure of pulmonary carcinoid tumours in Japan and in this and other countries requires further study. It would be of interest if comparable variations were shown in other racially distinct populations, bearing in mind the documented variation in incidence of these tumours in white and black Americans (Godwin, 1975).

Tateishi (1973) noted that the density of argyrophil 

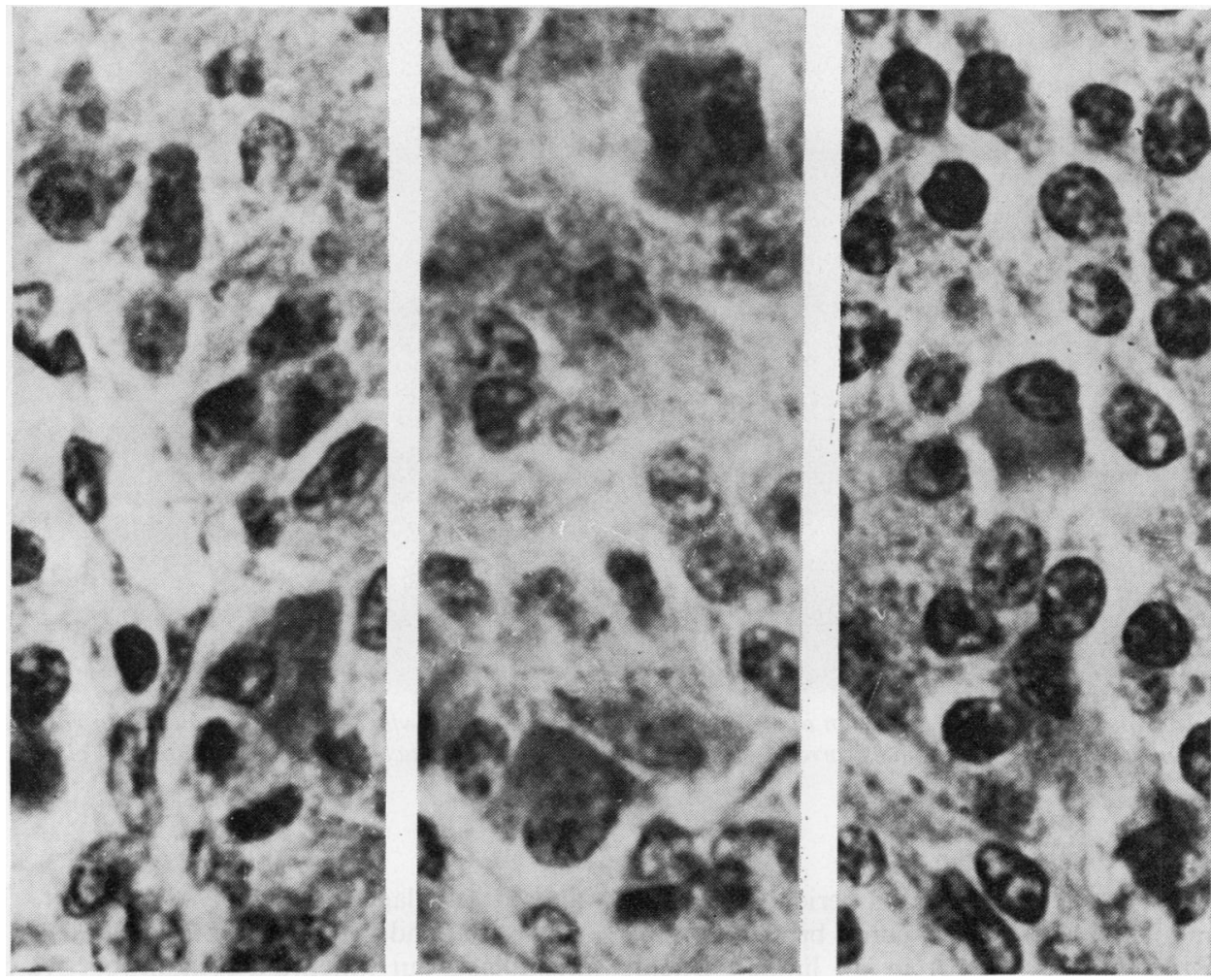

Fig. 6 Dense granular staining of the cytoplasm in occasional cells of six tumours incubated with anti-human calcitonin antiserum at a dilution of 1:160 (PAP counterstained with haematoxylin $\times 1250)$.

cell population in the bronchial mucosa increased with increasing distance from the hilum of the lung, being maximal in the bronchioles. In contrast, the majority of tumours derived from these cells (Bensch et al., 1965, 1968; Gmelich et al., 1967) occur in the larger and more central bronchi. In our series, only $18 \%$ of the tumours were peripheral, intermediate in the range of $13-25 \%$ documented by other authors (Burcharth and Axelsson, 1973; Salyer et al., 1975). Derivation of central tumours from occult, non-argyrophil endocrine cells has been suggested as a means of resolving this paradox (Tateishi, 1973), but whatever the functional stage of their progenitor, no distinctive cell or pattern type was identified among our peripheral pulmonary carcinoids. It is of interest that the clearly defined subgroup of peripheral tumours documented by Salyer et al. (1975) was characterised by spindle cell composition, anisocytosis, anisonucleosis, and overall disorganisation of structure. Our finding of peripheral tumours which generally resembled their central counterparts is consonant with the work of other authors (Felton et al., 1953; Bonikos et al., 1976). It is possible that the unmixed pattern seen in three of the peripheral lesions may have been related to size as two of the tumours were less than $1 \mathrm{~cm}$ diameter.

The atypical variant of pulmonary carcinoid tumour has a well recognised propensity for metastatic spread (Goodner et al., 1961; Arrigoni et al., 1972; Lawson et al., 1976; Okike et al., 1976). It is significant that these tumours were among the largest in our series (Table 2), which accords well with the experience of Arrigoni et al. (1972). Case 14, which metastasised, was also a large tumour but the mitotic rate was low. Perineural invasion (cases 7 and 9) was not related to the development of metastases, as noted previously (Markel et al., 1964; Marks and Lamberty, 1977).

In this series, as in others (Markel et al., 1964; Okike et al., 1976), bone formation was seen in approximately $30 \%$ of cases This phenomenon, which has been elegantly described by Price-Thomas and Morgan (1958), differs from age-associated 


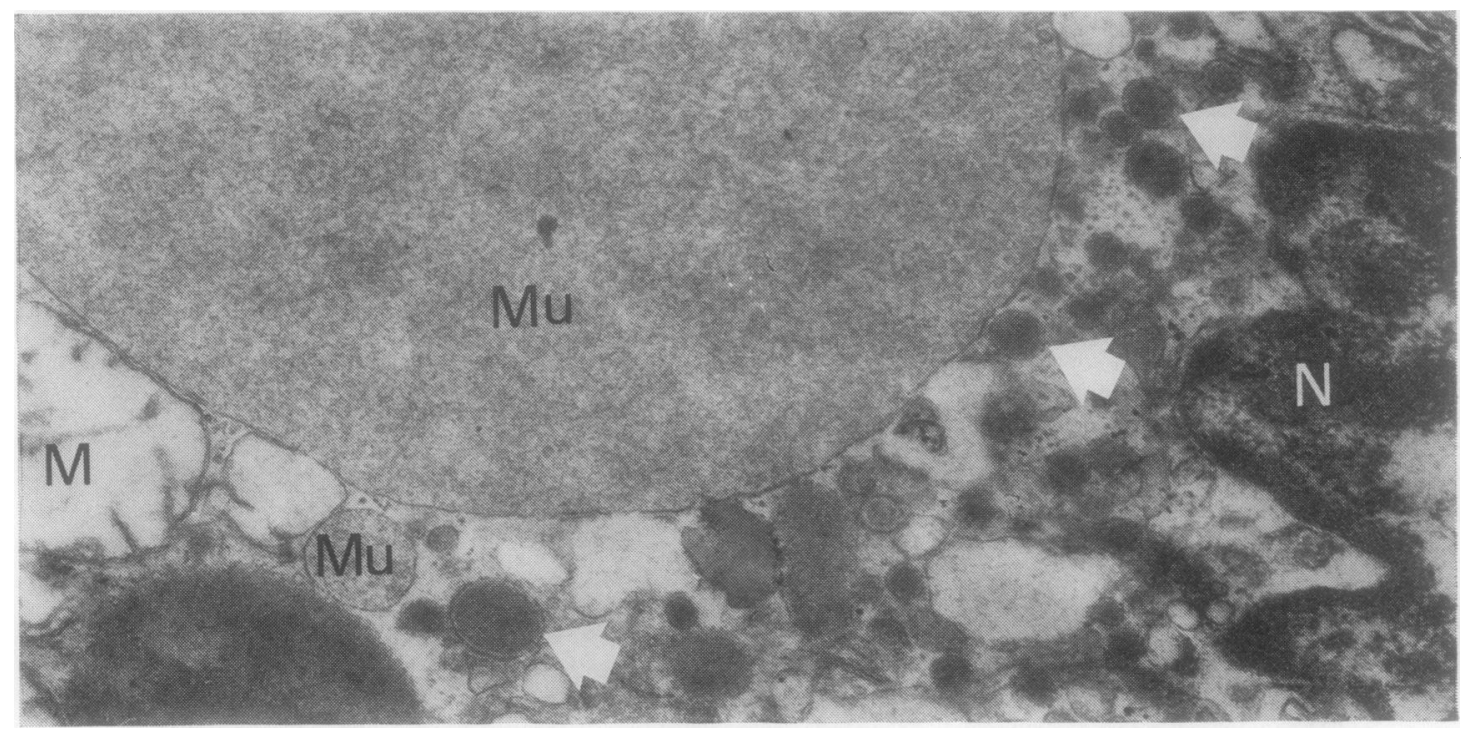

Fig. 7 Electron micrograph of a portion of a tumour cell from case 22 showing large and small mucin vacuoles $(\mathrm{Mu})$ and numerous neurosecretory granules (arrows). $M=$ mitochondria, $N=$ nucleus. Uranyl acetate/lead citrate $\times 30000$.

ossification (Spencer, 1977) in its perichondrial distribution and from tracheo- and broncho-pathia osteoplastica (Ashley, 1970) in its limited extent. The amount of bone formed in these tumours is rarely sufficient to be visible on chest $x$-ray (Lawson et al., 1976) and was not seen in any of our cases. The cause of this ossification is not known and there has been little speculation on its genesis. The intimate relationship of tumour and bronchial cartilage in these cases and the known propensity of carcinoids for producing polypeptide hormones suggests that high local concentrations of an osteogenic factor might be responsible. While ossification did not appear to be significantly related to any particular histological pattern in this series it was more common in argyrophilic tumours. The majority of bone metastases of medullary carcinoma of the thyroid exhibit new bone formation (Williams, 1975) related to a high local concentration of calcitonin. Secretion of calcitonin by carcinoid tumours has been recorded (Rosen and Weintraub, 1974; De Lellis and Wolfe, 1976; Welbourne and Joffe, 1977) and interestingly the majority of bony metastases from pulmonary carcinoid tumours also show new bone formation (Okike et al., 1976). Accordingly, we felt that locally produced calcitonin might be the factor responsible for ossification of cartilage in our pulmonary carcinoids. The presence of calcitonin containing cells in four tumours showing ossification and the absence of such cells in tumours without altered cartilage is possibly significant. The two cases (12 and 17) apparently devoid of osseous metaplasia but which did contain reactive cells may have been inadequately sampled. It is clear that this observation requires further study, and radioimmunoassay of tumour extracts would possibly yield more satisfactory results because the quantity of calcitonin detected by the immunoperoxidase technique appeared minute when compared with that visible in the control sections of a medullary carcinoma of thyroid.

Mucin production was found in five (23\%) of the tumours. All these showed a clearly tubular pattern in areas. We have commented elsewhere (Sweeney and Cooney, 1978) on the histogenetic problems raised by mucin production in pulmonary carcinoid. We feel it important to stress the possibility of incorrectly diagnosing as adenocarcinoma a poorly differentiated mucin-producing carcinoid (eg, case 22) as the prognosis in the latter is considerably better.

We thank Mr K. Shaw and Mr V. Lynch, Royal City of Dublin Hospital, for clinical details, F. A. Murray and J. Dunne for photographic and electron microscopic work, and Catherine Rezin and Colma Cunningham for technical assistance.

\section{References}

Arrigoni, M. G., Woolner, L. B., and Bernatz, P. E. 
(1972). Atypical carcinoid tumors of the lung. Journal of Thoracic and Cardiovascular Surgery, 64, 413-421.

Ashley, D. J. B. (1970). Bony metaplasia in trachea and bronchi. Journal of Pathology, 102, 186-188.

Bensch, K. G., Corrin, B., Pariente, R., and Spencer, H. (1968). Oat-cell carcinoma of the lung: its origin and relationship to bronchial carcinoid. Cancer, 22, 1163-1172.

Bensch, K. G., Gordon, G. B., and Miller, L. R. (1965). Electron microscopic and biochemical studies on the bronchial carcinoid tumour. Cancer, 18, 592-602.

Bonikos, D. S., Bensch, K. G., and Jamplis, R. W. (1976). Peripheral pulmonary carcinoid tumours. Cancer, 37, 1977-1998.

Burcharth, F., and Axelsson, C. (1973). Lung carcinoids. Scandinavian Journal of Thoracic and Cardiovascular Surgery, 7, 72-77.

Burns, J. (1975). Background staining and sensitivity of the unlabelled antibody-enzyme (PAP) method. Comparison with the peroxidase-labelled antibody sandwich method using formalin fixed paraffin-embedded material. Histochemistry, 43, 291-294.

De Lellis, R. A., and Wolfe, H. J. (1976). Calcitonin in spindle cell thymic carcinoid tumors (Letter). Archives of Pathology and Laboratory Medicine, 100, 340.

Donahue, J. K., Weichert, R. F., and Ochsner, J. L. (1968). Bronchial adenoma. Annals of Surgery, 167, 873-885.

Felton, W. L., Liebow, A. A., and Lindskog, G. E. (1953). Peripheral and multiple bronchial adenomas. Cancer, 6, 555-567.

Fisher, E. R., Palekar, A., and Paulson, J. D. (1978). Comparative histopathologic, histochemical, electronmicroscopic and tissue culture studies of bronchial carcinoids and oat cell carcinomas of lung. American Journal of Clinical Pathology, 69, 165-172.

Gmelich, J. T., Bensch, K. G., and Liebow, A. A. (1967). Cells of Kultschitsky type in bronchioles and their relation to the origin of peripheral carcinoid tumour. Laboratory Investigation, 17, 88-98.

Godwin, J. D. (1975). Carcinoid tumours: an analysis of 2,837 cases. Cancer, 36, 560-569.

Goodner, J. T., Berg, J. W., and Watson, W. L. (1961). The nonbenign nature of bronchial carcinoids and cylindromas. Cancer, 14, 539-546.

Hage, E. (1973). Histochemistry and fine structure of bronchial carcinoid tumours. Virchows Archiv $A$ Pathologische Anatomie, 361, 121-128.

Jones, R. A., and Dawson, I. M. P. (1977). Morphology and staining patterns of endocrine cell tumours of the gut, pancreas and bronchus and their possible significance. Histopathology, 1, 137-150.

Koikkalainen, K., Keskitalo, E., Luosto, R., and Taskinen, E. (1974). Carcinoid tumours and cylindromas of the tracheobronchial tree. Annales Chirurgiae et Gynaecologiae Fenniae, 63, 332-341.

Lawson, R. M., Ramanathan, L., Hurley, G., Hinson, K. W., and Lennox, S. C. (1976). Bronchial adenoma: review of an 18 year experience at the Brompton Hospital. Thorax, 31, 245-253.

Markel, S. F., Abell, M. R., Haight, C., and French, A. J. (1964). Neoplasms of bronchus commonly designated as adenomas. Cancer, 17, 590-608.

Marks, C., and Lamberty, J. (1977). The cellular structure of bronchial carcinoids. Postgraduate Medical Journal, 53, 360-363.

Meffert, W. G., and Lindskog, G. E. (1970). Bronchial adenoma. Journal of Thoracic and Cardiovascular Surgery, 59, 588-602.

O'Grady, W. P., McDivitt, R. W., Holman, C. W., and Moore, S. W. (1970). Bronchial adenomas. Archives of Surgery, 101, 558-561.

Okike, N., Bernatz, P. E., and Woolner, L. B. (1976). Carcinoid tumors of the lung. Annals of Thoracic Surgery, 22, 270-277.

Price-Thomas, C., and Morgan, A. D. (1958). Ossifying bronchial adenoma. Thorax, 13, 286-293.

Renault, P., and Verley, J. M. (1973). Les tumeurs carcinoides des bronches. Structure (microscopie optique et électronique) nosologie. Revue française des Maladies Respiratoires, 1, 211-238.

Rosen, S. W., and Weintraub, B. D. (1974). Ectopic production of the isolated alpha subunit of the glycoprotein hormones. New England Journal of Medicine, 290, 1441-1447.

Salyer, D. C., Salyer, W. R., and Eggleston, J. C. (1975). Bronchial carcinoid tumors. Cancer, 36, 1522-1537.

Smith, R. A. (1969). Bronchial carcinoid tumours. Thorax, 24, 43-50.

Soga, J., and Tazawa, K. (1971). Pathologic analysis of carcinoids: histologic re-evaluation of 62 cases. Cancer, 28, 990-998.

Spencer, H. (1977). Pathology of the Lung, 3rd edition, volume 1, p. 32. Pergamon Press, Oxford.

Sweeney, E. C., and Cooney, T. (1978). Mucin-producing atypical bronchial carcinoid. Journal of Clinical Pathology, 31, 1218-1225.

Tateishi, R. (1973). Distribution of argyrophil cells in adult human lungs. Archives of Pathology, 96, 198-202.

Tolis, G. A., Fry, W. A., Head, L., and Shields, T. W. (1972). Bronchial adenomas. Surgery, Gynaecology and Obstetrics, 134, 605-610.

Turnbull, A. D., Huvos, A. G., Goodner, J. T., and Beattie, E. J., Jr. (1972). The malignant potential of bronchial adenoma. Annals of Thoracic Surgery, 14, 453-464.

Weiss, L., and Ingram, M. (1961). Adenomatoid bronchial tumors: a consideration of the carcinoid tumors and the salivary tumors of the bronchial tree. Cancer, 14, 161-178.

Welbourne, R. B., and Joffe, S. N. (1977). The apudomas. In Recent Advances in Surgery, No. 9, edited by S. Taylor, pp. 311-334. Churchill Livingstone, Edinburgh and London.

Williams, E. D. (1975). Medullary carcinoma of the thyroid. In Recent Advances in Pathology, No. 9, edited by C. V. Harrison and K. Weinbren, pp. 157182. Churchill Livingstone, Edinburgh and London.

Williams, E. D., and Sandler, M. (1963). The classification of carcinoid tumours. Lancet, 1, 238-239.

Requests for reprints to: Dr E. C. Sweeney, c/o T. Kennedy, Holborn Hotel, Holborn Road, Holyhead, Isle of Anglesey. 